\title{
Papers
}

\section{c-erbB3 protein expression in ovarian cancer}

\author{
T Rajkumar, G W H Stamp, C M Hughes, W J Gullick
}

\begin{abstract}
Aims-To study the prevalence of overexpression of c-erbB3 growth factor receptor in ovarian carcinomas and to analyse its relation to histological subtype, stage and grade of the tumours.

Methods-Ninety eight ovarian carcinomas were evaluated immunohistochemically using the RTJ1 monoclonal antibody raised against a synthetic peptide, the sequence of which was derived from the cytoplasmic domain of the c-erbB3 protein.

Results-Of the tumours, $16 \%$ (16/98) overexpressed c-erbB3 protein relative to normal ovarian epithelium, whereas $22 \%$ (22/98) were completely negative. There was a statistically significant association between overexpression and well differentiated grade.

Conclusions-These findings suggest that c-erbB3 protein overexpression occurs in a significant proportion of ovarian cancers and is correlated with differentiation. Overexpression may merit further investigation as a potential prognostic indicator and as a target for new treatment. (F Clin Pathol: Mol Pathol 1996;49:M199-M202)
\end{abstract}

Keywords: c-erbB3 protein, overexpression, ovarian cancer.

Growth factor receptors with tyrosine kinase activity play an important role in cell growth and differentiation. These receptors have been subdivided into several families. The type 1 family includes the epidermal growth factor receptor (EGFR) and the c-erbB2, c-erbB3 and c-erbB4 receptors. Of these, EGFR and c-erbB2 have been studied widely, with regard to both their expression and function in tumours. ${ }^{1}$ Both were shown to be overexpressed or mutated in some cases and such changes can induce a transformed phenotype in experimental systems. By contrast, much less is known about the expression and function of the c-erbB3 protein.

The c-erbB3 protein seems to possess impaired tyrosine kinase activity. ${ }^{2}{ }^{3}$ Recent data have shown that Neu differentiation factor (NDF)/heregulin is a ligand for c-erbB3, although with a 10-fold lower affinity than for c-erbB $4 .^{4-6}$ The c-erbB3 protein has also been shown to heterodimerise with EGFR, c-erbB2 and c-erbB $4{ }^{78}$ and to synergise with c-erbB2 in transforming rodent fibroblasts. ${ }^{9}$ The c-erbB3 protein is expressed in a variety of normal tissues ${ }^{10}$ and is overexpressed in breast cancer cell lines ${ }^{112}$ and primary tumours, ${ }^{13-16}$ in pancreatic cancer, ${ }^{17}{ }^{18}$ gastric cancer ${ }^{1518}{ }^{19}$ and gastric cancer cell lines, ${ }^{20}$ colonic cancer, ${ }^{15} 18$ endometrial cancer, ${ }^{15}$ cervical cancer ${ }^{21} 22$ head and neck cancer ${ }^{18}$ and head and neck cancer cell lines ${ }^{23}$ in prostate cancer, ${ }^{15}{ }^{24}$ and lung cancer. ${ }^{15}$ Expression has been assessed in various studies at the mRNA and protein level but gene amplification was not observed in any case, ${ }^{111317202325}$ indicating that the overexpression seen probably resulted from increased gene transcription or increased mRNA stability, or both.

Of the gynaecological tumours, ovarian carcinoma has the highest incidence of mortality in western women. The EGFR and c-erbB2 proteins are expressed at low to moderate concentrations in normal ovarian epithelium. ${ }^{26}{ }^{27}$ Overexpression of EGFR has been studied by immunohistochemistry, northern analysis and radioreceptor assays, ${ }^{26} 2829$ whilst c-erbB2 overexpression has been studied by Southern, northern and western blotting, and by immunohistochemistry. ${ }^{27} 283031$ EGFR overexpression has been reported in between 26 and $77 \%$ of cases and is rarely the result of gene amplification. These very variable numbers may reflect different definitions of "overexpression", which seem to range from any expression to prominent membrane staining. c-erbB2 overexpression was seen in about $20-35 \%$ of cases. $^{27}{ }^{3031}$ Widely varying results have, however, been reported for gene amplification, ranging from 0 to $26 \%$. $^{32}$

Some reports have suggested that there is an association between poor prognosis and overexpression of EGFR and c-erbB2, ${ }^{26} 29$ although others have found no significant association with survival. ${ }^{31}{ }^{33}$ It is unclear what underlies these differences as the numbers in these studies were quite similar. One possible explanation is the patients sampled, as the mean survival times differ greatly between studies. ${ }^{32}{ }^{34}$

Two groups have now examined expression of c-erbB3 in ovarian cancer. Mandai et $a l^{35}$ reported elevated mRNA expression, detected by RT-PCR, in a proportion of cases and recently Simpson et $a l^{\beta 6}$ found raised concentrations of receptor protein. In this study we report the prevalence of c-erbB3 protein overexpression in ovarian cancer, examined by immunocytochemical staining and analyse its relation to some previously defined prognostic markers.

\section{Methods}

Ninety eight archival, formalin fixed, paraffin wax embedded ovarian carcinoma blocks were 
retrieved from the files at Hammersmith Hospital, London. The cases were a sequential series and blocks selected on the basis of representative and well presented cytoarchitecture were sectioned at $5 \mu \mathrm{m}$ and used for immunohistochemistry. Culture supernatant of RTJ1, a mouse IgM monoclonal antibody raised against a synthetic peptide, ${ }^{18}$ was used at a dilution of 1 in 20 in phosphate buffered saline (PBS) containing 1\% non-fat milk powder (Marvel). Immunohistochemical staining was performed using the $A B C$ technique, as described previously. ${ }^{18}$ An isotype matched negative control antibody (TEPC183) (Sigma, Poole, Dorset, UK) was used as a negative control on a section known to be strongly $(+++)$ positive for c-erbB3 protein in each run and this was also used as a positive control to adjust for staining intensity. The pattern of staining was heterogeneous in the tumours and hence they were scored for the percentage of positive tumour cells $(1=<25 \% ; 2=$ $25-50 \% ; 3=50-75 \% ; 4=>75 \%)$ and staining intensity $(1=$ weak $(+) ; 2=$ moderate $(++)$; 3 = strong $(+++)$; membrane staining was given an additional point). The scores were then added and a value exceeding 6 was considered indicative of a level of expression well above that seen in the normal ovarian surface epithelium. The tumours were also analysed in relation to the presence or absence of membrane staining alone, which has also been considered to be a sign of overexpression, particularly with regard to c-erbB2.
The tumour scores were then analysed for association with histological subtype. Grade of tumour was analysed by one of us (GWHS), as described previously. ${ }^{37}$ Staging was assessed on the basis of clinical information supplied on the specimen request form, or from the clinical notes. The $\chi^{2}$ test was used to assess statistical significance. Survival analysis was not performed as the patients had been treated with widely varying therapeutic regimens.

\section{Results}

The surface epithelium of the normal ovary was generally negative or weakly positive for c-erbB3 protein expression, ${ }^{10}$ but the ciliated epithelium of the Fallopian tubes was strongly stained, both on the cell membrane and in the cytoplasm. The tumours studied generally had a heterogeneous pattern of expression with regard to both percentage of positive tumour cells and staining intensity (figs $1 \mathrm{~A}$ and 1B). We therefore devised a scoring system as described in the Methods section and used this to determine whether any tumours showed overexpression relative to normal ovarian surface epithelium. Overexpression was considered present when the overall score for each tumour exceeded 6 points.

The tumours were divided into two groups, based on their score ( $\leqslant 6$ and $\geqslant 7$ ), and analysed for their association with histological subtype (table 1), stage (table 2) and grade (table 3). Of the tumours, $16 \%$ (16/98) overexpressed c-erbB3 protein, whereas $22 \%(22 / 98)$
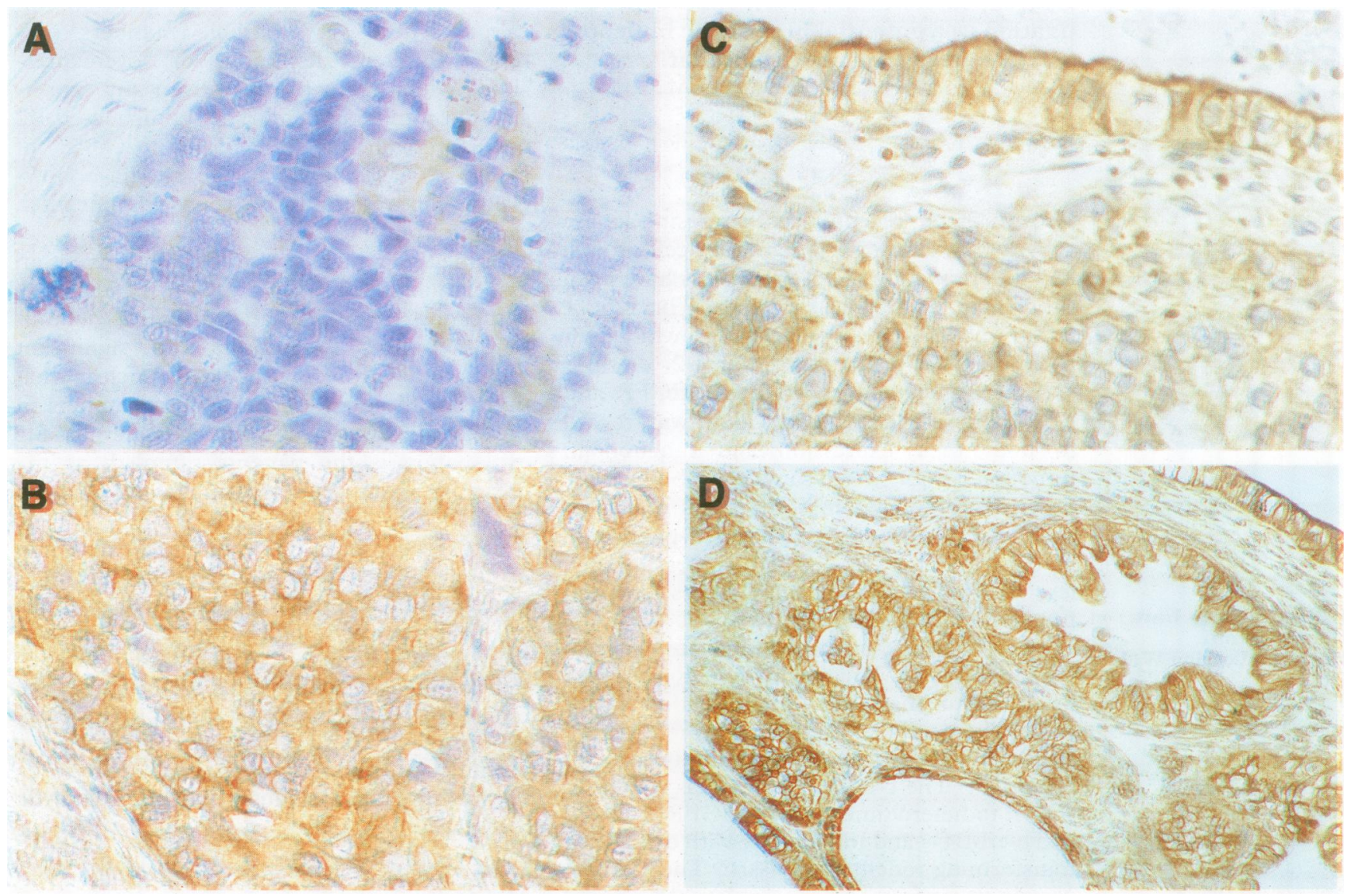

Figure 1 (A) Grade 3 ovarian carcinoma with weak heterogeneous cytoplasmic staining. (B) Grade 3 ovarian carcinoma with moderate heterogeneous cytoplasmic staining and membrane reactivity in a minority of cells. (C) Well and poorly differentiated areas of a serous carcinoma revealing differences in membrane and cytoplasmic localisation. (D) Grade 1 serous carcinoma showing strong membrane staining in all neoplastic cells. 
Table 1 Histological subtype v c-erbB3 score

\begin{tabular}{lrrr}
\hline & \multicolumn{3}{c}{ c-erbB3 score } \\
\cline { 3 - 4 } Histological subtype & $n$ & $\leqslant 6$ & $\geqslant 7$ \\
\hline Serous carcinomas & 37 & $30(1)$ & $7(6)$ \\
Mucinous carcinomas & 16 & $13(0)$ & $3(3)$ \\
Endometroid carcinomas & 15 & $13(1)$ & $2(2)$ \\
Clear cell carcinomas & 1 & $1(0)$ & $0(0)$ \\
Unclassified adenocarcinomas & 17 & $15(1)$ & $2(2)$ \\
Undifferentiated carcinomas & 10 & $9(0)$ & $1(1)$ \\
Mixed tumours & 2 & $1(0)$ & $1(1)$ \\
\hline
\end{tabular}

Numbers within brackets denote number of cases with membrane staining.

Table 2 Stage v c-erbB3 score

\begin{tabular}{llll}
\hline & \multicolumn{3}{c}{$c$-erbB3 score } \\
\cline { 3 - 4 } Stage & $n$ & $\leqslant 6$ & $\geqslant 7$ \\
\hline 1 & 34 & $27(0)$ & $7(7)$ \\
2 & 16 & $14(1)$ & $2(2)$ \\
3 & 43 & $36(2)$ & $7(6)$ \\
4 & 5 & $5(0)$ & $0(0)$ \\
\hline
\end{tabular}

$\chi^{2}$ test: $\mathrm{p}=0.67$

Numbers within brackets denote number of cases with membrane staining.

Table 3 Grade v c-erbB3 score

\begin{tabular}{llll}
\hline & \multicolumn{3}{c}{$c$-erbB3 score } \\
\cline { 3 - 4 } Grade & $n$ & $\leqslant 6$ & $\geqslant 7$ \\
\hline 1 & 23 & $15(0)$ & $8(8)$ \\
2 and 3 & 75 & $67(3)$ & $8(7)$ \\
\hline
\end{tabular}

$\chi^{2}$ test: $p=0.007$

Numbers within brackets denote number of cases with membrane staining.

Table 4 Scoring system $v$ membrane staining

\begin{tabular}{lll}
\hline & \multicolumn{2}{l}{ Membrane staining } \\
\cline { 2 - 3 } Score & Positive & Negative \\
\hline$\leqslant 6$ & $3(3.7 \%)$ & $79(96.3 \%)$ \\
$\geqslant 7$ & $15(93.75 \%)$ & $1(6.25 \%)$ \\
\hline
\end{tabular}

were completely negative. The histological subtype did not correlate significantly with c-erbB3 overexpression. There was, however, a statistically significant correlation between the well differentiated tumour grade and c-erbB3 overexpression ( $p=0.007$ ) (fig $1 \mathrm{C}$ ). Tumour stage did not correlate significantly with c-erbB3 expression $(\mathrm{p}=0.67)$.

Very similar results were obtained when membrane staining was used as an indicator of overexpression in that $18 \%$ of the tumours were positive (fig 1D). There was a strong correlation between the numerical scoring system and membrane staining (table 4 ). In addition, the association with tumour grade remained statistically significant $(p=0.019)$. In the three tumours which were membrane positive but had a score below 7, one was stained weakly with $25-50 \%$ of the tumour cells being positive; in the second $<25 \%$ of the tumour cells were positive with a strong staining intensity; the third had a moderate staining intensity with $25-50 \%$ positive tumour cells.

\section{Discussion}

This study describes the expression of the c-erbB3 protein in ovarian tumours and assesses the association of overexpression with some previously defined prognostic markers such as histological subtype, stage and grade. Of the ovarian carcinomas, $16 \%$ were found to overexpress c-erbB3 protein, whereas $22 \%$ were completely negative. It has not been determined in these neoplasms whether this results from increased transcription or gene amplification. Mandai et $a l^{35}$ have reported that c-erbB3 mRNA expression, detected using a quantitative RT-PCR assay, is raised in a proportion of ovarian cancers. Simpson et al, ${ }^{36}$ using the same antibody as used in the present study, tested 73 samples from 71 patients. Fifteen per cent of their cases were completely negative, $45 \%$ gave weak, $39 \%$ moderate and $16 \%$ strong staining. These authors, however, concluded that staining was largely homogeneous, observed occasional membrane staining and reported the lack of a significant association between overexpression and differentiation. In the present study, the same percentage of cases $(16 \%)$ exhibited strong staining but the well differentiated tumours were associated with c-erbB3 overexpression more frequently $(p=0.007)$ than the moderately or poorly differentiated ones. This association between c-erbB3 overexpression and well differentiated carcinomas was seen in both early (FIGO stages 1 and 2$)(p=0.048)$ and late stage disease (FIGO stages 3 and 4$)(p=0.04)$. These data suggest that c-erbB3 overexpression in ovarian carcinomas might act as a "good" prognostic marker. This is in contrast to the reported poor prognostic significance of EGFR and c-erbB2/HER2/neu in ovarian carcinomas. ${ }^{26} 2729$ Multivariate analysis on a larger series will be necessary to determine whether c-erbB3 overexpression provides any clinically useful independent prognostic information.

Membrane staining has generally been used as the sole indicator of overexpression of the c-erbB2 protein. In almost all of these studies the pattern of staining has been reported to be homogeneous, unlike the present study where the staining pattern was generally heterogeneous. In two of the cases in this series which were membrane positive but had a score $<7$, at least one of the parameters was at the lower end of the scale, one staining weakly ( + ) and in the other $<25 \%$ of tumour cells were positive for c-erbB3 expression. Another case negative for membrane staining had a score of $\geqslant 7$ (indicative of overexpression), $>75 \%$ of the tumour cells were c-erbB3 positive and stained strongly $(+++)$. These results emphasise that it desirable to use a scoring system which encompasses all of the relevant prognostic parameters, particularly when the staining pattern is heterogeneous.

The c-erbB 3 protein is expressed in the terminally differentiated cells of the normal skin, gastrointestinal and bladder epithelium, and in adult, but not in fetal, neurons. ${ }^{10}$ This is in contrast to EGFR expression, which is present in the basal proliferating cells of the same epithelia. The pattern of expression of c-erbB3 protein in normal tissues suggests that this protein has a potential role in differentiation in these tissues. NDF/heregulin has been described as a ligand for c-erbB4 as well as 
c-erbB3..$^{3-6}$ Recent data have shown that the c-erbB3 receptor forms heterodimers with EGFR, c-erbB2 or c-erbB4, suggesting that c-erbB3 has an additional role in the modulation of the effects of these receptors. ${ }^{5-9}$ It is not clear whether activation of c-erbB3 signalling mainly promotes cell division or cell differentiation. Its effect will also be conditioned by the degree of expression of other type 1 receptors with which it can interact.

In view of the fact that a proportion of cancers arising at several sites overexpress c-erbB3 protein, it may be possible to exploit this as a target for monoclonal antibodies conjugated to toxins, drugs or radioisotopes. Another promising approach would be to use antibody directed enzyme prodrug therapy (ADEPT). Monoclonal antibodies directed against growth factor receptors may also exert a synergistic effect in combination with chemotherapeutic agents, such as cisplatinum and doxorubicin. ${ }^{38}{ }^{39}$ We are currently exploring some of these approaches using a monoclonal antibody raised against the extracellular domain of the c-erbB3 protein. ${ }^{40}$

1 Salomon DS, Brandt R, Ciardiello F, Normano N. Epidermal growth factor - related peptides and their receptors in human malignancies. Crit Rev Oncol Hematol 1995;19:183232.

2 Prigent SA, Gullick WJ. Identification of c-erbB3 binding sites for phosphatidylinositol 3'kinase and SHC using an EGF receptor/c-erbB3 chimera. EMBO f 1994;13:2831-

3 Guy PM, Platko JV, Cantley LC, Cerione RA, Carraway KL. Insect cell-expressed p180 erbB 3 possesses an
KL. PM, Platko $\mathrm{JV}$, Cantley LC, Cerione RA, Carraway KL. Insect cell-expressed p180 erbB3 possesses an
impaired tyrosine kinase activity. Proc Natl Acad Sci USA impaired tyrosine

4 Kita YA, Barff J, Luo Y, Wen D, Brankow D, Hu S, et al. $\mathrm{NDF} /$ heregulin stimulates the phosphorylation of Her3/ erbB3. FEBS Lett 1994;349:139-43.

5 Carraway KL 3rd, Sliwkowski MX, Akita R, Platko JV, Guy PM, Nuijens A, et al. The c-erbB3 gene product is a receptor for Heregulin. 7 Biol Chem 1994;269:14303-6.

6 Plowman GD, Green KM, Culouscou JM, Carlton GW, Rothwell VM, Buckley S. Heregulin induces tyrosine phosphorylation of HER4/p180 $0^{\text {erbB4 }}$. Nature 1994; 366:473-5.

7 Riese DJ, van Raaij TM, Plowman GD, Andrews GC, Stern DF. The cellular response to neuregulins is governed by complex interactions of the erbB3 receptor family. Mol Cell Biol 1995;15:5770-6.

8 Beerli RR, Graus-Porta D, Woods-Cook K, Chen X, Yarden $\mathrm{Y}$, Hynes NE. Neu differentiation factor activation of ErbB-3 and ErbB-4 is cell specific and displays a differential requirement for ErbB-2. Mol Cell Biol 1995;15:6496505.

9 Alimandi M, Romano A, Curia MC, Muraro R, Fedi P, Aaronson SA, et al. Cooperative signaling of ErbB3 and ErbB2 in neoplastic transformation and human mammary carcinomas. Oncogene 1995;10:1813-21.

10 Prigent SA, Lemoine NR, Hughes CM, Plowman GD, Seldon C, Gullick WJ. Expression of the c-erbB-3 protein in
normal human adult and fetal tissues. Oncogene 1992; normal hum

11 Kraus MH, Issing W, Miki T, Popescu NC, Aaranson SA. Isolation and characterisation of ERBB3, a third member of the ERBB/epidermal growth factor receptor family: Evidence for overexpression in a subset of human mammary tumours. Proc Natl Acad Sci USA 1989; 86:9193-7.

12 Rajkumar T, Hollywood DP, Hurst HC, Gullick WJ. c-erbB-3 expression in breast tumour derived cell lines. The Breast 1995;4:84-91.

13 Lemoine NR, Barnes DM, Hollywood DP, hughes CM, Smith P, Dublin E, et al. Expression of erbB3 gene product in breast cancer. Brf 7 Cancer 1992;66:1116-21.

14 Gasparini G, Gullick WJ, Maluta S, Palma PD, Caffo O, Leonardi $\mathrm{E}$, et al. cerbB 3 and c-erbB2 gene expression in Leonardi $\mathrm{E}$, et al. cerbB 3 and c-erbB2 gene expression in node-negative breast carcinoma - an imm

15 Poller DN, Spendlove I, Baker C, Church R, Ellis IO, Plowman GD, et al. Production and characterisation of a polyclonal antibody to the c-erbB3 protein: Examination of c-erbB3 protein expression in adenocarcinomas. $f$ Pathol 1992;168:275-80

16 Quinn CM, Ostrowski JL, Lane SA, Loney DP, Teasdale J, Benson EA. c-erbB-3 protein expression in human breast cancer: comparison with other tumour variables and survival. Histopathology 1994;25:247-52.

17 Lemoine NR, Lobresco M, Leung H, Barton C, Hughes $\mathrm{CM}$, Prigent SA, et al. The erbB 3 gene in human pancreatic cancer. F Pathol 1992;168:269-73.

18 Rajkumar T, Gooden CSR, Lemoine NR, Gullick WJ. Expression of the c-erbB3 protein in gastrointestinal tract tumours determined by monoclonal antibody RTJ1. $\mathcal{f}$ Pathol 1993;170:271-8.

19 Sanidas EE, Filipe MI, Linehan J, Lemoine NR, Gullick WJ, Rajkumar T, et al. Expression of the c-erbB3 gene product in gastric cancer. Int $\mathcal{F}$ Cancer 1993;54:935-40.

20 Katoh M, Yazaki Y, Sugimura T, Terada M. c-erbB-3 encodes secreted as well as transmembrane receptor tyrosine kinase. Biochem Biophys Res Commun 1993; 192:1189-97.

21 Rajkumar T, Majhi U, Malligarjuna V, Shantha V, Gullick WJ. Prevalence of c-erbB 3 expression in squamous cell carcinomas of the cervix as determined by the monoclonal antibody RTJ2. Int $f$ Oncol 1995;6:105-9.

22 Hunt CR, Hale RJ, Armstrong C, Rajkumar T, Gullick WJ, Buckley CH. c-erbB-3 proto-oncogene expression in uterine cervical carcinoma. Int f Gynecol Cancer 1995; $5: 282-5$.

23 Issing WJ, Heppt WJ, Kastenbauer ER. erbB-3, a third member of the erbB/epidermal growth factor receptor family: its expression in head and neck cancer cell lines. Eur Arch Otorhinolaryngol 1993;250:392-5.

24 Myers RB, Srivastava S, Oelschlager DK, Grizzle WE. Expression of p160 erbB-3 and p185 erbB-2 in prostatic intraepithelial neoplasia and prostatic adenocarcinoma. $f$ Natl Cancer Inst 1994;86:1140-5.

25 Reifenberger G, Reifenberger J, Ichimura K, Meltzer PS, Collins VP. Amplification of multiple genes from chromosomal region 12q13-14 in human malignant gliomas: Preliminary mapping of the amplicons shows preferential liminary mapping of the amplicons shows preferential involvement of CD

26 Berchuck A, Rodriguez GC, Kamel A, Dodge KJ, Soper JT, Clarke-Pearson DL, et al. Epidermal growth factor expression in normal ovarian epithelium and ovarian cancer. $\mathrm{Am}$ F Obstet Gynecol 1991;164:669-74.

27 Berchuck A, Kamel A, Whitaker R, Kerns B, Olt G, Kinney $\mathrm{R}$, et al. Overexpression of HER2/neu is associated with poor survival in advanced epithelial ovarian cancer. Cancer Res 1990;50:4087-91.

28 Dingermann T, Leipold A, Landgraf S, Gebhart E, Tulusan $\mathrm{AH}$, Kersten W. Overexpression of cellular oncogenes in cystadenocarcinomas of the ovary. Int $f$ Oncol 1992; $1: 347-52$.

29 Scambia G, Benedetti Panici PB, Battaglia F, Ferrandina G, Baiocchi G, Greggi S, et al. Significance of epidermal growth factor receptor in advanced ovarian cancer. 7 Clin Oncol 1992;10:529-35.

30 Slamon DJ, Godolphin W, Jones LA, Holt JA, Wong SG, Keith DE, et al. Studies of the HER2/neu proto-oncogene in human breast and ovarian cancer. Science 1989; 244:707-12.

31 Rubin SC, Finstad CL, Wong GY, Almadrones L, Plante M, Lloyd KO. Prognostic significance of HER2/neu expression in advanced epithelial ovarian cancer: A multivariate analysis. Am f Obstet Gynecol 1993;168:162-9.

32 Leary JA, Edwards BG, Houghton CRS, Kefford RF, Friedlander ML. Amplification of HER $2 /$ neu oncogene in human ovarian cancer. Int f Gynecol Cancer 1992;2:291-4.

33 Haldane JS, Hird V, Hughes CM, Gullick WJ. c-erbB2 oncogene expression in ovarian cancer. F Pathol 1990; 162:231-7.

34 Singleton TP, Perrone T, Oakley G, Niehans GA, Carson L, Cha SS, et al. Activation of c-erbB2 and prognosis in ovarian carcinoma. Cancer 1994;73:1460-6.

35 Mandai $M$, Konishi I, Koshiyama M, Mori T, Arao S, Tashiro $\mathrm{H}$, et al. Expression of metastasis-related nm23-HI and $\mathrm{nm} 23-\mathrm{H} 2$ genes in ovarian carcinomas: Correlation with clinicopathology, EGFR, c-erbB2 and c-erbB3 genes, and sex steroid receptor expression. Cancer Res 1994; 54: $1825-30$.

36 Simpson BJB, Weatherill J, Miller EP, Lessells AM, Langdon SP, Miller WR c-erbB-3 protein expression in Langdon SP, Miller WR. c-erbB-3 protein exp
ovarian tumours. Br f Cancer 1995;71:758-62.

37 Foulkes WD, Ragoussis J, Stamp GWH, Allan GJ, Trowsdale J. Frequent loss of heterozygosity on chromosome 6 in human ovarian carcinoma. $\mathrm{Br} f$ Cancer 1993;67:551-9.

38 Fan Z, Baselga J, Masui H, Mendelson J. Antitumour effect of antiepidermal growth factor receptor monoclonal antibodies plus cis-Diamminedichloroplatinum on well established A431 cell xenografts. Cancer Res 1993; 53:4637-42.

39 Baselga J, Norton L, Masui H, Pandiella A, Coplan K, Miller WH Jr, et al. Antitumour effects of doxorubicin in combination with antiepidermal growth factor receptor monoclonal antibodies. $\mathcal{F}$ Natl Cancer Inst 1993;85:1327-

40 Rajkumar T, Gullick WJ. A monoclonal antibody to the extracellular domain of the c-erbB3 protein stimulates the anchorage-independent growth of breast tumour cell lines. Br F Cancer 1994;70:459-65. 